\title{
Financial management and competitiveness of tourism businesses
}

\author{
Brigin J. de Ávila ${ }^{\# 1}$, Raúl J. Martelo*2, David Franco ${ }^{* 3}$ \\ \# University of La Guajira, Riohacha, La Guajira, Colombia. \\ ${ }^{1}$ bricons.01@hotmail.com \\ * Faculty of Engineering, University of Cartagena, Cartagena, Bolívar, Colombia. \\ ${ }^{2}$ rmartelog1@unicartagena.edu.co \\ 3.dfrancon@unicartagena.edu.co
}

\begin{abstract}
The objective of this research was to determine the relationship between financial management and competitiveness of tourism sector companies in the Colombian-Venezuelan border. The research was applied, cross-sectional, descriptive and correlational with no experimental and field design, supported by the survey instrument, which was applied to the administrators and financial managers of tourism companies. As a result, it was obtained that the majority qualified with a high level of presence of the indicators. Likewise, it was concluded that there is a consistent correlation between the variables financial strategies and competitiveness, by identifying financial planning and competitiveness for the success of tourism businesses in the Colombian-Venezuelan border.
\end{abstract}

Keyword - Financial management, Competitiveness, Planning

\section{INTRODUCTION}

According to the World Tourism Organization, during the last six decades, tourism has experienced a continuous expansion and diversification, becoming one of the largest economic sectors and growth in the world [1]. The arrival of international tourists grew by 5\% worldwide in 2013, reaching a record 1,087 million arrivals. With respect to Colombia, there was a growth of 5\% in 2013, from which a good result was obtained with respect to previous years. Likewise, Venezuela received 25.2\% more international tourists in 2012, all of them from Colombia, Brazil, the United States, Spain and Italy, reporting a 45.1\% increase in revenue from incoming tourism, compared to 2011.

According to the long-term forecasts prepared by the UNWTO, included in Tourism by 2030, the arrival of international tourists worldwide will grow 3.3\% annually between 2010 and 2030 to reach 1800 million in 2030 . To accommodate these figures, Colombia and Venezuela have regions with high growth and positioning of the hotel industry. With regard to Colombia, cities such as Bogotá, Medellín, Cartagena and Santa Marta have a good hotel capacity; in the case of Venezuela, there are Caracas and Isla Margarita, however, this situation does not characterize the border region of Venezuela, especially in the northern border municipalities (Department of La Guajira and Zulia State), which have low capacity, quality, technology management and innovation in this sector.

Under this perspective of global and regional tourism development, this tourism sector requires solid, flexible and innovative organizations, derived from an efficient application of scientific processes of administration and management, in order to achieve efficiency in decision-making in order to make them competitive in a global market that every day is more demanding in terms of expectations and needs of customers [2]. Consequently, the greatest responsibility of managers is to find alternatives to achieve profitability and achieve a competitive leadership position [3]. In this sense, financial management turns out to be a fundamental axis in the general process of strengthening and development of companies, as well as an indispensable support for financial decision-making [4].

However, tourism companies located in the border region of Venezuela have not assumed the reality of the global environment, due to administrative deficiency and lack of innovative solutions to face the challenges imposed by the economic dynamics. The main objective of this research is to determine the relationship between financial management and the competitiveness of tourism companies in the Colombo-Venezuelan border, in order to be more competitive in this era of economic globalization.

\section{Methodology}

The present investigation is of a descriptive, correlational type, due to the fact that information will be collected on the variables financial management and competitiveness in tourist companies in the ColomboVenezuelan border, based on their dimensions and indicators and the scope in which they are developed, to determine how your behavior is. Since it contains two variables, it is correlational, basically to determine the degree to which the variables in one or several factors are related to each other [5]. Likewise, it is classified as cross-sectional, descriptive and correlational with non-experimental and field design, because the data are 
collected directly from the reality or observed phenomenon, which allowed to verify the true conditions in which the data were obtained.

\section{A. Population}

The population was constituted by tourist companies located on the Colombo-Venezuelan border, which represent the largest reception of tourists from the two countries in question. We found: 152 hotels, 149 restaurants and 101 travel agencies that sell tour packages. In the selection of the sample, the following was taken into account: a finite population of 402 executives in the financial area of the tourist operating companies working with a confidence level of $95.0 \%$, a margin of error of $10 \%$, complementary proportions of $\mathrm{p}$ and $\mathrm{q}$ equal to 0.5 , replaced in Formula 1.

$$
n=\frac{Z^{2} p q N}{e^{2}(N-1)+Z^{2} p q}
$$

Wherein:

n: sample size

$\mathrm{Z}^{2}: \mathrm{Z}$ critical

$\mathrm{p}$ and $\mathrm{q}$ : complementary proportions

$\mathrm{e}^{2}$ : sampling error.

The previous procedure yielded a representative sample of 84 informants, who were surveyed for the purposes of establishing the information corresponding to the investigation, distributed as follows: 32 hotels, 31 restaurants and 21 travel agencies for a total of 84 respondents.

\section{B. Research instruments}

According to the design and type of research, the techniques to be used are observation and survey. From the collection of information through the survey, the questionnaire was used as an instrument, which allows obtaining direct and reliable information, provided it is done with systematized controlled procedures, through complete audiovisual media, especially in the study of the behavior of people at your workplace [6]. Similarly, a questionnaire with 57 items was designed, 30 to measure the Financial Management variable and 27 to measure the competitiveness variable. The questions of the questionnaire were designed according to the Likert scale, providing each question with five alternatives that are: totally in agreement, in agreement, neither in agreement nor disagreement, in disagreement and totally in disagreement.

Also, a code of 1 to 5 was assigned for tabulation (Table 1). The assignment of the code or coding consists in assigning to each category of response a different number or letter, which will serve to group the answers or observations that are identical or that at least appear as equivalents [6].

TABLE I. Likert scale to measure attitudes

\begin{tabular}{|c|c|}
\hline Scale & Attitudes \\
\hline 5 & Totally agree \\
\hline 4 & Agree \\
\hline 3 & Neither agree nor disagree \\
\hline 2 & In disagreement \\
\hline 1 & Totally disagree \\
\hline
\end{tabular}

Designed the instrument, it was subjected to a study for its validity, for which it was resorted to the trial of five experts, taken from the academic committee of the Master of Business Management at the Rafael Belloso Chacín University, who evaluated and contributed suggestions on the relevance and writing of variables, dimensions and indicators (in hierarchical order). Likewise, the reliability was determined by using the Alfa Cronbach internal consistency coefficient, replacing the Formula 2 with the required values.

$\alpha=\left[\frac{K}{K-1}\right]\left[\frac{\sum_{i=1}^{K} S_{i}^{2}}{S_{t}^{2}}\right]$

Wherein:

$\mathrm{S}_{\mathrm{i}}^{2}$ : sum of variances of each item.

$\mathrm{S}_{\mathrm{t}}^{2}$ : variance of the total rows (total score of the judges)

$\mathrm{K}$ : number of questions or items. 


\section{Data analysis}

For the analysis and processing of the data, descriptive statistics were used. A double-entry matrix table was designed, where the data provided by the subjects were recorded and the mean, median, and modeling were extracted, as well as the measures of dispersion, mean deviation, and standard deviation. Likewise, for the analysis a comparative scale of an arithmetic mean was used (Table 2), which allows to establish the behavior of the variables based on the answers obtained and the characterization of the variables financial management and competitiveness.

TABLE II. Comparison Scale

\begin{tabular}{|c|c|}
\hline Intervals & Categories \\
\hline $1,00 \geq \mathrm{x}<1,80$ & Very low \\
\hline $1,80 \geq \mathrm{x}<2,60$ & Low \\
\hline $2,60 \geq \mathrm{x}<3,40$ & medium \\
\hline $3,40 \geq \mathrm{x}<4,20$ & high \\
\hline $4,20 \geq \mathrm{x} \leq 5,00$ & Very high \\
\hline
\end{tabular}

The scale was designed to take into account the number of items contained in the instrument and the categorization of the different response alternatives. Its interpretation was based on the statistical analysis carried out with the data obtained from the informants in the survey. To tabulate the data obtained, a double entailed matrix was elaborated where the scores of the answer alternatives were presented and the statistics were calculated to measure the phenomenon under investigation.

\section{RESULTS}

After the classification and collection of information, the data were ordered and analyzed and interpreted through the elements of analysis, each of the dimensions, sub-dimensions and indicators. Table 3 shows the results of the variable financial management, Dimension: Financial Planning.

TABLE III. Financial planning

\begin{tabular}{|c|c|c|c|c|c|c|c|c|c|c|c|}
\hline \multirow{3}{*}{ Financial planning } & \multicolumn{10}{|c|}{ Response options } & \multirow{3}{*}{$\begin{array}{l}\text { Arithmetic } \\
\text { mean by } \\
\text { indicator }\end{array}$} \\
\hline & \multicolumn{2}{|c|}{$\begin{array}{l}\text { Totally } \\
\text { agree }\end{array}$} & \multicolumn{2}{|c|}{ Agree } & \multicolumn{2}{|c|}{$\begin{array}{l}\text { Neither } \\
\text { agree nor } \\
\text { disagree }\end{array}$} & \multicolumn{2}{|c|}{$\begin{array}{c}\text { In } \\
\text { disagreement }\end{array}$} & \multicolumn{2}{|c|}{$\begin{array}{c}\text { Totally } \\
\text { disagree }\end{array}$} & \\
\hline & Af & $\mathrm{Rf}$ & Af & $\mathrm{Rf}$ & Af & $\mathrm{Rf}$ & Af & $\mathrm{Rf}$ & Af & $\mathrm{Rf}$ & \\
\hline Financial Forecast & 69 & 27.38 & 149 & 59.13 & 21 & 8.33 & 6 & 2.38 & 7 & 2.78 & 4.06 \\
\hline $\begin{array}{l}\text { Investment } \\
\text { projects }\end{array}$ & 85 & 33.73 & 137 & 54.37 & 18 & 7.14 & 7 & 2.78 & 5 & 1.98 & 4.15 \\
\hline Budgets & 81 & 32.14 & 139 & 55.16 & 20 & 7.94 & 9 & 3.57 & 3 & 1.19 & 4.13 \\
\hline Financial plan & 76 & 30.16 & 142 & 56.35 & 22 & 8.73 & 7 & 2.78 & 5 & 1.98 & 4.11 \\
\hline Financial Policies & 98 & 30.16 & 120 & 56.35 & 21 & 8.73 & 6 & 2.78 & 7 & 1.98 & 4.17 \\
\hline
\end{tabular}

For the results shown in Table 3, the indicator "Financial Forecast" indicates that the majority of the companies studied show that the development and application of this indicator leads to the development of financial plans. The results agree with what was stated by [7], when he states that financial forecasting is a key element in the success or failure of a given decision and therefore predictive models are developed capable of determining the future behavior of a given phenomenon.

The results of the indicator "Investment Projects" indicate that there is ignorance of the contributions of organizational investment projects of some members of the companies. In this regard, the projects are carried out to meet the needs of customers, but they are also used to exploit the resources and capacities established to deliver certain business results, increase productivity or sales of goods and services, and know if the implementation of these projects is profitable [8].

Regarding the indicator "Budget", the results lead to the lack of commitment of some of the members of the companies under study. In this regard, the literature strongly links the strategy and the budget, and defines the budget as a "quantitative expression of an action plan proposed by the administration for a future time" [9]. In addition, this element is used to allocate financial resources to the people who are responsible for managing the funds. This allows them to achieve corporate goals and objectives [10]. 
The indicator "Financial Plan" indicates that most companies have excellent financial planning contributing to business success; On the other hand, the indicator Financial Policies show that most companies use and implement financial policy to make sound decisions.

When analyzing the arithmetic mean of each one of the indicators, it was obtained that all were qualified with a high level of presence in the development of financial planning in the companies, a result which was also reflected in the general arithmetic mean.

Obtained with the results, it is evident that the financial planning is a broad subject that requires a general vision of integration, and confirm the exposed in [11], where a model for the financial planning is exposed incorporating the time and the expected nature of financial events. Also, in [12] the relationship between the general financial policies of companies and their pension plans was investigated; and in [13], they conclude that companies must adjust their policies taking into account the interdependence between alternative financial instruments for decision making.

Now, the Financial Management dimension presents the results shown in Table 4.

TABLE IV. Financial Management

\begin{tabular}{|c|c|c|c|c|c|c|c|c|c|c|c|}
\hline \multirow{3}{*}{$\begin{array}{c}\text { Financial } \\
\text { Management }\end{array}$} & \multicolumn{10}{|c|}{ Response options } & \multirow{3}{*}{$\begin{array}{c}\text { Arithmetic } \\
\text { mean by } \\
\text { indicator }\end{array}$} \\
\hline & \multicolumn{2}{|c|}{$\begin{array}{l}\text { Totally } \\
\text { agree }\end{array}$} & \multicolumn{2}{|c|}{ Agree } & \multicolumn{2}{|c|}{$\begin{array}{l}\text { Neither } \\
\text { agree nor } \\
\text { disagree }\end{array}$} & \multicolumn{2}{|c|}{$\begin{array}{c}\text { In } \\
\text { disagreement }\end{array}$} & \multicolumn{2}{|c|}{$\begin{array}{l}\text { Totally } \\
\text { disagree }\end{array}$} & \\
\hline & Af & $\mathrm{Rf}$ & Af & $\mathrm{Rf}$ & Af & $\mathrm{Rf}$ & Af & $\mathrm{Rf}$ & Af & $\mathrm{Rf}$ & \\
\hline $\begin{array}{l}\text { Financial } \\
\text { decision making }\end{array}$ & 107 & 42.46 & 123 & 48.81 & 10 & 3.97 & 11 & 4.37 & 1 & 0.40 & 4.29 \\
\hline $\begin{array}{l}\text { Financial } \\
\text { Leadership }\end{array}$ & 108 & 42.86 & 120 & 47.62 & 15 & 5.95 & 9 & 3.57 & 0 & 0.00 & 4.30 \\
\hline \multicolumn{11}{|c|}{ Arithmetic mean dimension } & 4.30 \\
\hline
\end{tabular}

The indicator "Financial decision making" shows that for most companies surveyed there are better decision making in financial management, which implies that managers make the investment decisions proposed to ensure that only those who contribute are made positively to the value of the company. In this regard, financial decision-making is fundamental for financial management, since most of these not only affect decision-making, but also other elements, such as investments in financial markets that are usually made through a money manager who decides on behalf of his client [14].

Similarly, for the indicator "Financial leadership" the results lead to better financial leadership but poor management of it. In this regard, [15] affirms that within companies, financial leadership is the tool that helps strategic decision-making, which should focus on strengthening the basic objective of financial management in its two components: on the one hand, to generate sufficient income (financial resources) for the proper functioning of the business, and on the other to guarantee the efforts and demands in financial management in accordance with the policies of the organization.

Finally, from the arithmetic mean of each of the indicators, it was obtained that for financial decision-making, there is a very high level of presence and a high level regarding the relationships of decision-making and financial leadership, of which He deduces that there is good decision-making and financial leadership that are fundamental for financial management, because through this the success or failure of an organization can be defined.

Regarding the Financial Control dimension, which helps to identify the control of the companies studied, the results are shown in Table 5.

TABLE V. Financial control

\begin{tabular}{|c|c|c|c|c|c|c|c|c|c|c|c|}
\hline \multirow{3}{*}{ Financial control } & \multicolumn{10}{|c|}{ Response options } & \multirow{3}{*}{$\begin{array}{c}\text { Arithmetic } \\
\text { mean by } \\
\text { indicator }\end{array}$} \\
\hline & \multicolumn{2}{|c|}{$\begin{array}{l}\text { Totally } \\
\text { agree }\end{array}$} & \multicolumn{2}{|c|}{ Agree } & \multicolumn{2}{|c|}{$\begin{array}{c}\text { Neither } \\
\text { agree nor } \\
\text { disagree }\end{array}$} & \multicolumn{2}{|c|}{$\begin{array}{c}\text { In } \\
\text { disagreement }\end{array}$} & \multicolumn{2}{|c|}{$\begin{array}{l}\text { Totally } \\
\text { disagree }\end{array}$} & \\
\hline & \multicolumn{2}{|c|}{ Af } & \multicolumn{2}{|c|}{ Af } & \multicolumn{2}{|c|}{ Af } & \multicolumn{2}{|c|}{ Af } & \multicolumn{2}{|c|}{ Af } & \\
\hline Financial indicators & 89 & 34.92 & 138 & 54.37 & 16 & 7.54 & 8 & 2.78 & 1 & 0.40 & 4.21 \\
\hline Financial diagnosis & 105 & 41.67 & 123 & 48.81 & 10 & 3.97 & 13 & 5.16 & 1 & 0.40 & 4.26 \\
\hline $\begin{array}{l}\text { Audit to financial } \\
\text { processes }\end{array}$ & 81 & 33.10 & 109 & 44.68 & 29 & 11.51 & 26 & 10.32 & 6 & 0.40 & 4.09 \\
\hline \multicolumn{11}{|c|}{ Arithmetic mean dimension } & 4.19 \\
\hline
\end{tabular}


The indicator "Financial Indicators", the majority of respondents agree that the development of these leads to measure the effectiveness and behavior of organizations.

For "Financial Diagnosis", it was observed that the majority agrees with the indicator and in contrast there is a low tendency in disagreement, which indicates the ignorance of the financial diagnosis in some members of the companies.

On the other hand, the indicator "Audit to Financial Processes" evidences the lack of knowledge of the audit of financial processes in a small number of the members of the companies.

The arithmetic mean is evidence for the "Financial Indicators", a result with a very high level of presence, while the indicators "Financial Diagnosis" and "Audit of Financial Processes", show a high level in the rating, that is, all Qualify in a high level of presence in the development of Financial Control, to achieve an efficient, effective and effective financial management in companies. Finally, the dimension shows an arithmetic mean of the high level of presence of Financial Control. In this sense, the results agree with the definition of [16], which defines financial control as the set of activities and tools that allow financial managers to carry out financial analyzes for internal and external control purposes, in order to keep control both the return on capital invested and the cost of resources obtained from investors.

Table 6 below shows the results of the characterization of the competitive factors in the companies providing tourism services in the border area of Venezuela.

TABLE VI. Determining Factors of Competitiveness

\begin{tabular}{|c|c|c|c|c|c|c|c|c|c|c|c|}
\hline \multirow{3}{*}{$\begin{array}{c}\text { Determining } \\
\text { Factors of } \\
\text { Competitiveness }\end{array}$} & \multicolumn{10}{|c|}{ Response options } & \multirow{3}{*}{$\begin{array}{l}\text { Arithmetic } \\
\text { mean by } \\
\text { indicator }\end{array}$} \\
\hline & \multicolumn{2}{|c|}{$\begin{array}{c}\text { Totally } \\
\text { agree }\end{array}$} & \multicolumn{2}{|c|}{ Agree } & \multicolumn{2}{|c|}{$\begin{array}{c}\text { Neither agree } \\
\text { nor disagree }\end{array}$} & \multicolumn{2}{|c|}{$\begin{array}{c}\text { In } \\
\text { disagreement }\end{array}$} & \multicolumn{2}{|c|}{$\begin{array}{c}\text { Totally } \\
\text { disagree }\end{array}$} & \\
\hline & Af & Af & Af & Af & Af & Af & Af & Af & Af & Af & \\
\hline Innovation & 95 & 37,70 & 125 & 49,60 & 14 & 5,56 & 14 & 5,56 & 4 & 1,59 & 4,16 \\
\hline Quality & 100 & 39,68 & 111 & 44,05 & 19 & 7,54 & 11 & 4,37 & 11 & 4,37 & 4,10 \\
\hline $\begin{array}{c}\text { Customer } \\
\text { service }\end{array}$ & 103 & 39,86 & 118 & 45,83 & 9 & 6,35 & 16 & 5,58 & 6 & 2,38 & 4,17 \\
\hline \multicolumn{11}{|c|}{ Arithmetic mean dimension } & 4,15 \\
\hline
\end{tabular}

The indicator "Innovation", shows that a large part of the respondents are in agreement with the development and application of this within the companies, however, a low number of them do not coincide with the fact that innovation does not lead to the development of the objectives set.

For the indicator "Quality", a large part of the respondents establish it as a determining factor for the competitiveness of the companies, a result that they place as opposed to a low number of them.

The indicator "Customer Service" shows that the majority tend to apply the indicator; it is evident that there is an adequate response attitude towards clients, which contributes to the achievement of quality as a determining factor. However, a small part of the population does not show approval or disapproval regarding the referred indicator.

When analyzing the arithmetic mean of each of the indicators, it was found that "Innovation", "Quality" and "Customer Service" are located at a very high level of presence. Finally, the dimension shows an arithmetic mean that shows a high level of presence of determinants of competitiveness. In this regard, [17] tourism competitiveness is assessed, and it is concluded that the city's tourism competitiveness conceptual model is the basis for assessing the competitiveness of tourism, emphasizing that external environmental factors have an impact on internal environmental factors and both form the conditions for the competitiveness of tourism.

Besides, Table 7 of the Competitive Advantages dimension expresses the results shown in the analysis.

TABLE VII. Determining Factors of Competitiveness

\begin{tabular}{|c|c|c|c|c|c|c|c|c|c|c|c|}
\hline \multirow{3}{*}{$\begin{array}{l}\text { Competitive } \\
\text { advantages }\end{array}$} & \multicolumn{10}{|c|}{ Response options } & \multirow{3}{*}{$\begin{array}{c}\text { Arithmetic } \\
\text { mean by } \\
\text { indicator }\end{array}$} \\
\hline & \multirow{2}{*}{\multicolumn{2}{|c|}{$\begin{array}{c}\begin{array}{c}\text { Totally } \\
\text { agree }\end{array} \\
\text { Af }\end{array}$}} & \multirow{2}{*}{\multicolumn{2}{|c|}{$\frac{\text { Agree }}{\text { Af }}$}} & \multirow{2}{*}{\multicolumn{2}{|c|}{$\begin{array}{c}\text { Neither agree } \\
\text { nor disagree }\end{array}$}} & \multirow{2}{*}{\multicolumn{2}{|c|}{$\begin{array}{c}\begin{array}{c}\text { In } \\
\text { disagreement }\end{array} \\
\text { Af }\end{array}$}} & \multirow{2}{*}{\multicolumn{2}{|c|}{$\begin{array}{c}\begin{array}{c}\text { Totally } \\
\text { disagree }\end{array} \\
\text { Af }\end{array}$}} & \\
\hline & & & & & & & & & & & \\
\hline Tangible resources & 75 & 29.76 & 144 & 57.14 & 22 & 8.73 & 7 & 2.78 & 4 & 1.59 & 4.11 \\
\hline Intangible resources & 89 & 35.32 & 132 & 52.38 & 19 & 7.54 & 5 & 1.98 & 7 & 2.78 & 4.15 \\
\hline Distinctive skills & 90 & 39.68 & 116 & 38.49 & 35 & 16.28 & 9 & 4.76 & 2 & 0.79 & 4.11 \\
\hline \multicolumn{11}{|c|}{ Arithmetic mean dimension } & 4.12 \\
\hline
\end{tabular}


For the indicator "Tangible resources" and "Intangible resources", the majority agrees that there are competitive advantages over these resources in companies, while a small part indicates that they do not agree or disagree, as well as affirm that the mentioned resources they do not lead to a competitive advantage.

For its part, the indicator "Distinctive skills", a large number of respondents agreed that there are competitive advantages over the distinctive skills that companies have, while the remaining members indicate disagreement, disagreement and equally agree that the Distinctive skills do not lead to achieving a competitive advantage. According to [18], it considers that the competitive advantages are factors that allow a company to stand out against its competitors either in the characteristics of the product or service or in aspects such as customer service, distribution channels and price, among others, which will be reflected in a greater participation in the market.

By analyzing the arithmetic mean of each of the indicators, a very high level of presence was obtained for the "Tangible resources", while "Intangible resources" and "Distinctive skills" qualify at a high level of presence as competitive advantages through of intangible resources and distinctive skills in companies. Finally, the dimension shows an arithmetic mean that indicates the existence of a high level of presence of competitive advantages.

Next, in Table 8, the results obtained from the Competitive Strategies dimension are shown.

TABLE VIII. Determining Factors of Competitiveness

\begin{tabular}{|c|c|c|c|c|c|c|c|c|c|c|c|}
\hline \multirow{3}{*}{$\begin{array}{l}\text { Competitive } \\
\text { strategies }\end{array}$} & \multicolumn{10}{|c|}{ Response options } & \multirow{3}{*}{$\begin{array}{c}\text { Arithmetic } \\
\text { mean by } \\
\text { indicator }\end{array}$} \\
\hline & \multirow{2}{*}{\multicolumn{2}{|c|}{$\begin{array}{c}\text { Totally } \\
\text { agree }\end{array}$}} & \multirow{2}{*}{\multicolumn{2}{|c|}{$\frac{\text { Agree }}{\text { Af }}$}} & \multirow{2}{*}{\multicolumn{2}{|c|}{$\begin{array}{c}\text { Totally } \\
\text { agree }\end{array}$}} & \multirow{2}{*}{\multicolumn{2}{|c|}{$\frac{\text { Agree }}{\text { Af }}$}} & \multirow{2}{*}{\multicolumn{2}{|c|}{$\begin{array}{c}\begin{array}{c}\text { Totally } \\
\text { agree }\end{array} \\
\text { Af }\end{array}$}} & \\
\hline & & & & & & & & & & & \\
\hline $\begin{array}{l}\text { Leadership in } \\
\text { low costs. }\end{array}$ & 89 & 40.48 & 112 & 38.89 & 25 & 9.13 & 26 & 7.54 & 0 & 3.97 & 4.07 \\
\hline Differentiation & 78 & 30.16 & 130 & 51.59 & 23 & 9.13 & 11 & 4.37 & 10 & 4.76 & 4.01 \\
\hline Focus & 68 & 27.38 & 122 & 48.41 & 39 & 15.08 & 11 & 4.37 & 12 & 4.76 & 3.89 \\
\hline \multicolumn{11}{|c|}{ Arithmetic mean dimension } & 3.99 \\
\hline
\end{tabular}

The indicator "Leadership in Low Costs", resulted that a large part considers that the indicator leads to the development of competitive strategies of companies, different from the remaining population, who are opposed to what has been said. From the above it is inferred that leading companies enjoy competitive advantages in costs thanks to economies of scale, field or the effects of the experience curve.

With respect to the "Differentiation" indicator, almost $20 \%$ coincide with the fact that the development of the differentiation element does not lead to the development of plans related to competitive strategies.

The "Focus" indicator as a competitive strategy reaches $75 \%$ agreed to use the approach as a competitive strategy, while the remaining population indicates that the approach as a competitive strategy does not lead to the development of plans. Likewise, when analyzing the arithmetic mean of each of the indicators, a high level of presence in the development of competitive strategies was obtained for all. Finally, the dimension shows an arithmetic mean with a high level of presence. The results confirm and verify that there is a close relationship between the variables financial management and competitiveness.

To finish with the results obtained, the following guidelines are proposed to optimize the financial management and competitiveness of the companies providing tourism services in the Colombo-Venezuelan Border Zone:

- A process of selection and capture of new financial income, taking into account that it is the fundamental moment for companies to increase their capital or financial assets

- Bring an efficient, effective and efficient budget management, that is, take advantage of the synergy of experienced financial leaders in the area of financial planning.

- Implement an adequate financial strategy to carry out its diagnosis, financial forecast and prepare an adequate budget, as well as established the financial controls and, if necessary, apply an audit to all financial processes, in accordance with an organizational structure that contain a financial department that responds to the needs of analysis, planning and control of resources.

Equally, constant innovation and quality in its products or services is proposed where the customer service prevails as the maximum expression of the companies investigated, bearing in mind that the customer is always right. It is also proposed to constantly review and evaluate the tangible and intangible resources available to companies, and take into account the distinctive skills that allow them to obtain competitive advantages with respect to companies that offer tourism services in Venezuela and Colombia. Finally, we invite you to 
strengthen the competitive strategies related to leadership in low costs with special differentiating characteristics in your products or services and under a different approach that allows you to occupy the market segment of the tourism sector.

\section{CONCLUSION}

The following is concluded:

Regarding the financial management variable, all of them qualify the development of Financial Planning in a high level of presence, bearing in mind that this is the fundamental axis in the operations of a company through structures that allow it to guide, coordinate and control the activities for the achievement of the proposed objectives. Regarding the description of the financial management, internal and external factors must be taken into account that may affect the normal activities of the companies to mitigate the risks and make the best decisions. Similarly, it is concluded that all the companies investigated have a high appreciation that the control is the measurement and correction of performance to ensure that the objectives of the company and the plans designed to achieve them are achieved.

Regarding the characterization of competitiveness factors, all qualify in a high level of presence the development of the determining factors to achieve true efficiency and effective management of competitiveness in the elements of innovation, quality and customer service, where competitiveness is a neuralgic point in the achievement of organizational objectives. Regarding the description of the competitive advantages of the companies, there is a positive trend in terms of tangible and intangible resources, as well as the distinctive skills and it is concluded that the competitive advantages are factors that allow the company to stand out against its competitors either by the characteristics of the product or service or by aspects such as customer service, distribution channels, price, among others.

Similarly, it concludes by examining the competitive strategies present in the companies studied, that there is a high level of presence in the development of indicators such as leadership in low costs, differentiation and focus. Regarding the determination of the relationship of financial management and the competitiveness of companies, it is concluded that there is a consistent correlation between the variables financial strategies and competitiveness, by identifying financial planning and competitiveness for the success of companies in the tourism sector.

\section{REFERENCES}

[1] UNWTO (United Nations World Tourism Organization), UNWTO Panorama of international tourism, 2014 ed. Madrid, España: UNWTO, 2004.

[2] C. Raßfeld, D., Rößle, and R. Jochem, "Integrated and modular design of an optimized process architecture," International Journal of Production Management and Engineering, vol. 1, issue 1, pp. 63-75, 2013.

[3] E. Twineyo, The Basics of Business Management - Vol I. Leadership, Financial Management and Economics. Bookboon, 2017.

[4] A. Furnham and H. C. Boo, "A literature review of the anchoring effect," The Journal of Socio-Economics, vol. 40, issue 1, pp. 35-42, 2011.

[5] E. Babbie, The basics of social research, 5th ed. Belmont: Wadsworth Cengage Learning, 2011.

[6] R. Kumar, Research methodology, a step by step guide for beginners, 3rd ed. SAGE, 2003.

[7] R. D. A. Araújo, "A robust automatic phase-adjustment method for financial forecasting," Knowledge-Based Systems, vol. 27, pp. 245-261, 2012.

[8] E. Vuori, K. Artto, and L. Sallinen, "Investment project as an internal corporate venture," International Journal of Project Management, vol. 30, issue 6, pp. 652-662, 2012.

[9] A. Bhimani, C. Horngren, S. Datar, and G. Foster. Management and Cost Accounting, 4th ed. Harlow: Pearson, 2008.

[10] R. Messer, "Budgets and other lies: Evidence of bias in financial planning," Business Horizons, vol. 60, issue 4, pp.447-453, 2017.

[11] N. Chieffe and G. K. Rakes, "An integrated model for financial planning," Financial Services Review, vol. 8, issue 4, pp.261-268, 1999.

[12] S. M. Bartram, "In Good Times and in Bad: Defined-Benefit Pensions and Corporate Financial Policy," Journal of Corporate Finance, vol. 48, pp. 331-351, 2018.

[13] J. A. Colombo and J. F. Caldeira, "The Role of Taxes and the Interdependence among corporate financial policies: Evidence from a natural experiment," Journal of Corporate Finance, In Press, 2017.

[14] S. C. Füllbrunn and J. W. Luhan, "Decision making for others: The case of loss aversion," Economics Letters, vol. 161, pp.154-156, 2017.

[15] Available http://www.eumed.net/tesis-doctorales/2006/asc/4p.htm

[16] M. Renzetti, “Corporate Finance: Financial Control,” International Encyclopedia of the Social \& Behavioral Sciences (Second Edition), pp. 927-931, 2015.

[17] A. Cibinskiene and G. Snieskiene, "Evaluation of city tourism competitiveness," Procedia-Social and Behavioral Sciences, vol. 213, pp. 105-110, 2015.

[18] Available http://www.degerencia.com/articulo/1a_relevancia_de_las_ventajas_com 


\section{AUTHOR PROFILE}

Brigin J. de Ávila works as part-time professor at the University of La Guajira (Colombia). Mr. de Ávila completed his magister from Rafael Belloso Chacín University. Mr. de Ávila completed his undergraduate in Industrial Engineering at the University of La Guajira.

Raúl J. Martelo works as full-time professor at the University of Cartagena (Colombia). Mr. Martelo completed his magister from Industrial University of Santander (Colombia). Mr. Martelo completed his undergraduate in Systems Engineering at the Industrial University of Santander.

David Franco works as full-time professor at the University of Cartagena (Colombia). Mr. Franco completed his magister from Monterrey Institute of Technology and Higher Education (México). Mr. Franco completed his undergraduate in Systems Engineering at the Technological University Foundation Comfenalco. 